\title{
Cultural Differences and C-E Advertising Translation
}

\author{
HU Chun-xiao \\ Zhejiang Gongshang University, Hangzhou, China
}

\begin{abstract}
The present paper aims to explore the activity of translating Chinese advertisements into English across cultural barriers. First, the functional views of Skopostheorie are introduced which can be served as theoretical supports for advertising translation. An attempt is then made to analyze the cultural errors existed in C-E (Chinese-English) advertising translation. They are the literal translation of some stereotyped expressions in Chinese advertisements, the lack of knowledge of the different consumer expectations in two cultures and the neglect of the difference of committing in Chinese and English advertisements. This paper suggests three methods to solve the problems: (1) adding explanations to the names of special Chinese products; (2) imitating the household proverbs and poetry in the West; and (3) making appropriate adaptations of certain cultural elements in the original advertisement. All methods suggested are proved feasible by a number of examples so as to gain certain enlightenment of dealing with the cultural aspects of advertising translation.
\end{abstract}

Keywords: Skopostheorie, advertising translation, cultural differences

\section{Introduction}

As an applied language, advertising is developing rapidly. Advertisements have direct effects on people's daily life in many aspects, and with the social progress and economic development, the effects will become even stronger. Being a tool serving economy, the advertising translation is a very important research problem. Lund (1947) had classified the objectives of advertising into five aspects: attract attention, arouse interest, stimulate desire, create conviction, and get action. Association of National Advertising of America has made a similar definition as ACCA (i.e., awareness, comprehension, conviction, and action), which requires the language used in advertisements must be firstly appellative and persuasive. Therefore, in advertising translation, "faithfulness" is not in the first place as in the literary or scientific translation. In order to achieve the promotional function of an advertisement in a target culture, the translator can make some adaptations on the basis of the information offered by the original text, taking account of the presumed interests, expectations, knowledge, and situational constraints of the target-culture addressees. This paper thus introduces Skopostheorie, a functionalist approach, as a theoretical guidance on advertising translation across cultural barriers.

\section{Skopostheorie}

Skopostheorie first proposed by Vermeer (1987), who has played a major role in the development of functionalism, focusing on the function or functions of texts and translations. The word "Skopos" is a technical

HU Chun-xiao, lecturer, Hangzhou College of Commerce, Zhejiang Gongshang University. 
term for the aim or purpose of a translation. Every translation is directed at an intended audience, since to translate means "to produce a text in a target setting for a target purpose and target addressees in target circumstances” (Vermeer, 1987). In Vermeer's terms, the target text should conform to the standard of “intratextual coherence” (Vermeer, 1987). This means the receiver should be able to understand it; it should make sense in the communicative situation and culture in which it is received. However, since a translation is an offer of information about a preceding offer of information, it is expected to bear some kind of relationship with the corresponding source text. Vermeer (1987) called this relationship "intertextual coherence" or "fidelity". Fidelity is considered subordinate to intratextual coherence, and both are subordinate to the skopos rule (Nord, 1997, p. 12). In Skopostheorie, the standard for judging the validity of a translation is not the "equivalence" between the translated text and the original one, but the extent to which the prospective functions are achieved in the target situation.

The primary function of an advertisement is to stimulate the receivers' desire to purchase a particular product. It tries to appeal to their real or imagined needs, describing those qualities of the product that are presumed to have positive values in the receivers' value system. Similarly, whether the translated text can serve the same promotional function in a target culture as the source advertisement in the original one depends on the extent to which receptors understand and appreciate the translated text. Therefore, the functional views of Skopostheorie can serve as theoretical supports for advertising translation.

\section{Identifying the Existing Problems in C-E (Chinese-English) Advertising Translation}

By comparing the Skopos with the source text functions before starting to translate, translators should be able to locate the problems that will arise in the translating process. They should thus be able to devise a holistic strategy for their solution (Nord, 1997). Translation errors can be functionally classified into four categories: pragmatic, cultural, linguistic, and text-specific. This paper mainly concerns cultural translation errors, which are "due to an inadequate decision with regard to reproduction or adaptation of cultural-specific conventions” (Nord, 1997). Cultural translation errors are common problems in a number of translated English advertisements from the Chinese.

\section{Literally Translating the Conventional Chinese Expressions}

The literal translation of certain Chinese phrases may be unacceptable in English, though they are perfectly natural and entirely appropriate in Chinese. For example, “老少皆宜” can often been seen in many food advertisements in our country in order to emphasize the wide range of their prospect consumers. It is a good and sound Chinese expression. However, it would not translate the Chinese phrase into "suitable to the old and young”, which ignores "old” as a euphemism in Western culture. Examples (1)-(4) are given below to show how “老少皆宜” can be rendered into acceptable English

Example (1) Leephick 花旗参茶: “efficacious for grownups and children”.

Example (2) 鹰牌花旗参茶: “the most convenient and effective health drink and refreshment for both sexes of all ages and in all season”.

Example (3) 多美滋 (Dumex) 奶粉: “convenient for ensuring healthy nourishment for growing children and the whole family". 
Example (4) Contadina 食品: “now Contadina offers you pastes \& sauces to target every consumer segment".

Similarly, the literal translation of some stereotyped expressions in Chinese advertisements would sound queer to the native English speakers. Consider Examples (5)-(7):

Example (5) 省优部优: awarded the superior quality product by the provincial government and the Ministry concerned

Example (6) 信誉第一, 顾客至上: reputation first and consumers the utmost

Example (7) 在有关部门的领导下, 取得了很大的进步: It makes great improvement under the leadership of the sectors concerned.

The exact translations of Chinese advertising formula into English may be grammatically correct, but the manner of expression does not stylistically match original English advertisements. Instead of convincing people, the word for word renderings would confuse foreign readers and even arouse displeasure.

\section{Lacking Understanding of the Different Consumer Expectations}

As we know, Chinese and Western people have different ways of thinking. Without knowledge of the different consumer expectations in two cultures, a translator can hardly make his translated text appellative to the target culture receivers. For instance, a Chinese food advertisement usually gives prominence to the scientific process, which can be seen from common statements like “引进国外先进技术”, “高科技技术”, and “用科学方 法”, while the Western counterpart highlights the naturalness of food. There is such an advertisement exacted from a Chinese magazine for a kind of ginseng soft sweets (see Example (8)).

Example (8) 经几代技术人员的努力, 吸取现代先进工艺之精华, 该产品既保持了口味纯正、糖体 晶荣的特点, 有增添了芬芳浓郁、咀嚼适口的感觉，令您食而不忘。

The English version right following the Chinese text is a literal translation: "It's the result of many years of intensive studies done by the technical personnel of our factory and is refined with modern advanced technology. The product has a glistening luster, a thick fragrance as well as a pure and delicious taste. Once you eat this sweet, you'll never forget it”.

However, how can an advertisement based on the Chinese way of thinking attract foreign readers' attention? The following translation shows the improvement made by a successive revision, which stresses "naturalness" so as to suit the Western consumer preference: "The natural flavor is improved by years of researched state of the art technology. Our candy reserves in its glistening amber-like jerry the natural fragrance of the virgin forest. It melts on your tongue with a lasting sweetness”.

\section{Overlooking the Different Advertising Commitments}

The Chinese and English way of committing is also different. Traditional Chinese culture upholds overwhelming superiority so that gaining a "golden" prize can often be a sound evidence of the good quality of a certain product. Though some English advertisements also have authoritative supports, they seem less convincing to the Western consumers than the results from experiments or marketing surveys (LIAO \& JIANG, 2011, p. 381). However, the difference of committing in Chinese and English advertisements has not got enough attention by some translators. Here is a sample (see Example (9)):

Example (9) $x$ x x-the health bodyguard of the people x x x Vital Herb-Belt , a new external-use health car product, is made up of natural herb. Based 
on theories of traditional Chinese medicine and referring to the health care therapies of ancient dynasties, it is invented by Mr. x x x, an expert on external treatment of internal diseases. x x x Vital Herb-Belt has been appraised by the most famous traditional Chinese medical experts. It can increase the immunity of human body, delay aging, adjust autonomic nerve function and increase sex function. It also has perfect medical effects on chromic gastritis, diarrhea, constipation, sexual failure. Besides it is effective to diseases of respiratory tract, cardicvessel, nervous system and urinary system. Containing neither hormone nor poison nor side effect, it is a safe, handy and effective health-care produce which can treat diseases and make you stronger if you have no disease.

Since it was invented, it has won 65 international and national prizes and enjoyed the confidence of patients.

Wish you good health and a long life accompanied by the $\mathrm{x} x \mathrm{x}$ Vital Herb-Belt.

Obviously, the above commitments do not accord with the Westerners' way to measure truth, that is, let the facts speak for themselves. How can the herb-belt be reliable without any data from clinical experiments or any appraisal by authorities? The commitments are totally groundless. Professor Les from York University in Canada once analyzed the frequency of 14 categories of information appeared in Chinese magazine advertisements. According to his statistics, information from marketing researches in Chinese magazine advertisements was less than one percent (LI, 2010, p. 76). Therefore, a Chinese translator should be very aware of the Western consumers' belief that "facts speak louder than words" especially when putting Chinese advertisements into English. Advertising translation problems connected with the promotional function should be solved according to a strategy, which will ideally lead to the translation type acceptable in another culture. The method used in the following translating practice can set a good example (see Example (10)).

Example (10) 华夏始建于1949年5月，至今已有40多年悠久历史，业务关系遍及世界，是一个具有 丰富经验，享有良好信誉，以航运为主的综合性运输公司…

FARENCOL was founded in May 1945, with a history of over 40 years. It has established business relations all over the world. FARENCOL is a comprehensive transportation business specialized in shipping...

By comparing the two language versions, it can be found that the translator has intentionally neglected the outlined statements in the original Chinese text so as to let the facts themselves convince English readers.

\section{Dealing With the Cultural Aspects in Advertising Translation}

\section{Translating the Names of Special Chinese Products}

The purpose of advertising translation is to promote a certain product to people in another country, thus it is of crucial importance to transmit the image of the product invariantly to the readers of the translated text. However, it is difficult to put names of some special Chinese products into English due to the different cultural conventions. In order to keep the image of the product invariant, a translator should add explanations or corresponding replacements where necessary. Comparing the following original translated text and the revised version (see Example (11)):

Example (11) 溪口千层饼采用传统工艺，制作精细，质地松脆，清香可口。 
The original translation: "Xikou Thousand-sheeted cake is home made, using natural foods and traditional procedures. The cake tastes good, smells good and is crisp".

The Chinese name of “千层饼” aims to emphasize the sheets of this particular cake are much more than those of ordinary cakes, not representing the exact number. The literal translation as "Thousand-sheeted cake" is likely to cause misunderstanding in the English readers. Look at the improvement made in the revised version: "Xikou Qianceng Cake, with numerous clear sheets in it, is finely made in a traditional way. It is tasty and crisp".

The revision has not only improved the loose structure of the original translation, but also precisely introduce the special Chinese food to the Western people.

Here is another example (see Example (12)):

Example (12) 曹州城内有一隅首，名曰“尤之女”。据传尤之女酿得一手好酒，偶被孔子一饮，赞 曰：“圣贤至美!”故得名“圣酒”。(曹州圣酒)

The original translation: “There is an intersection named 'Girl Youzhi' in Caozhou city. The story goes that Girl Youzhi made a good kind of liquor with 'Confucius' drank by accident. He praised this liquor to be 'a delicious one'. So it got its name as Liquor 'Shengjiu'”.

Putting the improper use of vocabulary aside, we only concern the translation of traditional Chinese terms in the above sample. First, "Confucious" is not well known in Western countries, an additional explanation like "the great Chinese educator" is quite necessary. Second, the praise made by Confucious in a genteel manner involves knowledge on traditional Chinese expressions. In ancient China, liquor of the highest grade was often likened to the sage men. Accordingly, the revision as "excellent" would more in keeping with the original degree of appreciation than the word "delicious". Finally, the transliteration of "Shengjiu" cannot convey its rich connotations in Chinese, and if changed to "Saint Liquor" it seems much better.

The examples mentioned reflect the cultural diversity that exists. Certain traditional Chinese terms mean little or nothing without some sort of additional explanation. A few, however, do have equivalents in English. A translator is required to apply translating methods in a flexible way.

\section{Using Parody}

Parody is most effective method that contributes much to the attention value of an advertisement. Through imitating the household advertisements, proverbs, and poems in the West, one can make his translated texts more impressive and easy to remember. A study of several examples will illustrate this (see Examples (13)-(16))::

Example (13) “黑妹牙膏”，强健牙龈，保护牙齿。

Don’t show me any other. But show me Black Sister.

The translation of this advertisement is inspired by the English advertisement of the typewriters with "Brother” brand of Japan. Their original text is: "Don't say 'Give me another'. Say 'Give me Brother’”. The repeated use of "Show me" has the effect of contrast and stress, indicating that potential consumers just want to buy "Black Sister" . Compared with the original text, the artistic effect of the parody is better than the original one (FANG, 2003, p. 156).

Example (14) 红玫相机新奉献

My love's like a Red Rose!

The translation is a copy of the famous love poem "My Love’s Like a Red, Red Rose” (LI, 2010, p. 88), 
which is widely read among Western people. It well expresses a consumer's fondness for Red Rose Camera, hoping the brand will gain a general appeal as Robert Burns' poetry.

Example (15) 谁跑到最后, 谁笑得最好。(轮胎广告)

He laughs best who runs longest.

Example (16) 人到山前必有路, 有路必有双星鞋。

Where there is a road, there are Double Star Shoes.

The former is rendered in imitation of the English proverb "He laughs best who laughs last" while the latter imitates a common saying "Where there is a will, there is a way". The two translated advertisements have not only achieved functional equivalence with the source texts, but also added emotional appeal to the products being promoted.

\section{Making Adaptation}

As we have seen, the main idea of Skopostheorie could be paraphrased as "the translation purpose justifies the translation procedures” (Nord, 1997). The advertising translation is not a cultural communication, but a way to promote products to intended audience in another culture. Therefore, adaptations of cultural elements in the original advertisement are needed to ensure everyone in the target situation understands the translated text.

Some words giving good or beautiful impression in Chinese culture may have negative meanings in English culture. Take “Dabao SOD” (大宝SOD蜜) brand for example. People who are familiar with Chinese will associate "SOD蜜” with something sweat and soft. It seems that we can smell the aroma on the users' body. But if it is sold as "Dabao SOD" in foreign countries, English customers will have an awful feeling after a glimpse at it. "SOD" in English is used as a term of abuse to a man, showing annoyance and sudden anger. Similarly, the cultural associations of certain creatures are also different. For instance, the Mandarin Ducks are the symbol for love between couples in Chinese culture. But to the Western minds, they do not arouse such association (DENG \& LIU, 1989). So “驾鸯牌枕头” is better to be translated as “Lovebirds Pillowcase”. It should also be mentioned that when translating Chinese advertisements into English, care should be taken with Western consumers' psychology. The reason why “轻身牌减肥片” found no market for a time in America where weight-reducing had always been a fashion was the original translation as "obesity-reducing Tablets" aroused displeasure in Western consumers. Soon after the translation was changed into "slimming pills", the medicine began to have a good sale.

In short, appropriate readjustment is not only permissible in advertising translation, but a necessity.

\section{Conclusions}

The promotional function of the translated text is predominant in advertising translation. Care must be taken with the cultural elements to make the target audience appreciate the translated version and finally ignite their desire for a certain product. To counter the cultural errors existed in C-E advertising translation, three methods are suggested as solutions. Some sort of additional explanation to the literal translation of the traditional Chinese term can ensure to transfer the image of the product adequately; using parody makes the translated advertisement more impressive and smooth; adaptation is especially effective in dealing with cultural barriers. All methods suggested are proved feasible by a number of examples. However, further consultation with professional translators is also necessary. 


\section{References}

DENG, Y. C., \& LIU, R. Q. (1989). Language and culture: Comparison of English and Chinese language and culture. Beijing: Foreign Language Teaching and Research Press.

FANG, M. Z. (2003). Pragmatic translation studies (p. 156). Qingdao: Dingdao Press.

FENG, X. W. (2010). On aesthetic and cultural issues in pragmatic translation-based on translation of brand names and brand slogans. Shanghai: Shanghai Jiao Tong University Press.

LI, K. X. (2010). Advertisement translation: A theoretical and practical approach. Beijing: Beijing University Press.

LIAO, G. Q., \& JIANG, L. R. (2011). CE translation of practical writing: Theory, strategies and practice (p. 381). Beijing: National Defence Industry Press.

Lund, J. V. (1947). Newspaper advertising. New York: Prentice-Hall.

Nord, C. (1997). Translation as a purposeful activity: Functional approaches explained (pp. 30-33). Manchester: St. Jerome Publishing.

QIN, X. B. (2002). Essentials of English stylistics. Shanghai: Shanghai Foreign Language Education Research.

Vermeer, H. J. (1987). What does it mean to translate?. Indian Journal of Applied Linguistics, 13(2), 25-33. 